\title{
An Empirical Study of College English PAD Class Based on Self-Determination Theory
}

\author{
Xiaoping Mai ${ }^{1}$ \\ ${ }^{1}$ School of Foreign Studies, Lingnan Normal University, Zhanjiang, China \\ Correspondence: Xiaoping Mai, School of Foreign Studies, Lingnan Normal University, Zhanjiang, China.
}

Received: October 2, 2021

Accepted: November 21, 2021

Available online: November 23, 2021

doi:10.11114/ijsss.v10i1.5408

URL: https://doi.org/10.11114/ijsss.v10i1.5408

\begin{abstract}
Motivation is one of the important factors that affect the success of foreign language learning. It determines the participation, consciousness, enthusiasm and persistence of foreign language learners. Based on the self-determination theory, this study conducted a survey of 280 non-English majors from a university in southern China through questionnaire and semi-structured interviews to investigate how college English PAD Class meet the basic psychological needs of students' autonomy, competence and relatedness. The data of the questionnaire were described and analyzed using SPSS statistical software and the interviews were analyzed using qualitative content analysis as a method. The results show that PAD Class has a good effect in mobilizing students' initiative in learning, promoting the development of students' thinking ability, and building a harmonious teacher-student relationship. The advanced teaching concept and rigorous teaching design adopted in PAD Class have certain enlightening significance for teaching reform.
\end{abstract}

Keywords: foreign language learning, pad class, motivation, self-determination theory

\section{Introduction}

In response to the main problems existing in the current university classrooms, Chinese scholar Zhang Xuexin (2014) proposed a teaching model called PAD Class (Presentation - Assimilation - Discussion). The teaching concept is to combine teacher lectures and student discussions, allocate half of the class time to teachers, and the other half to students to discuss, and stagger the discussion time, so that students have one week after class to arrange their own learning and conduct personalized internalization and absorption. In PAD Class, the teaching activities are divided into three links, namely presentation, assimilation and discussion. At the presentation stage, teachers give intensive lectures on the teaching content in the classroom to help students understand the framework of knowledge and the focus and difficulties of learning. At the second stage, students internalize knowledge into personal experience by reading textbooks or other materials after classroom teaching, which is a process of independent learning and thinking. At the discussion stage, students bring their own learning results to the class and communicate with other students in class, which can be divided into group discussions and inter-group discussions.

The core concept of PAD Class teaching model is to divide power and responsibility. Through teachers and students sharing power and responsibilities in the teaching process, it promotes students' active learning, cultivates their core qualities and innovative abilities, and achieves comprehensive and healthy personality development (Zhang, 2016). PAD Class preserves the advantages of the lecturing and collaborative learning paradigms and avoid their disadvantages. Since its first success in 2014, the PAD method has gained national popularity in China and been successfully put into practice by thousands of college teachers in nearly all subjects. The author has implemented PAD Class teaching in her college English class since September 2015 and achieved good results. This paper attempts to use the self-determination theory to evaluate the PAD Class teaching of college English, and to explore some basic ideas of this model in stimulating students' learning motivation and satisfying students' basic psychological needs.

\section{Literature Review}

\subsection{Self-determination Theory}

Self-determination theory is a theory of learning motivation proposed by American psychologists Deci and Ryan (1985). It mainly focuses on the learning motivations of students with different degrees of autonomy (such as internal 
motivation, external regulation motivation, introverted regulation motivation and identity regulation motivation) and its different effects. Through experiments, researchers have concluded three basic psychological needs: autonomy, competence, and relatedness. In this theory, the need for autonomy is the need for self-determination, and the satisfaction of this need is the most important. When an individual feels a high degree of self-determination in an activity, he experiences an internal attribution and feels that he can dominate his activity. At this time, his internal motivation to participate in this activity is very high. Competence need refers to the individual's belief that his learning behavior or actions can reach a certain level, and that he can be competent for the activity. The need for relatedness means that the individual needs care, understanding, and support from the surrounding environment or other people to experience a sense of belonging. Therefore, if the external environment supports and promotes the satisfaction of these three needs, then students' learning motivation will be further improved. Several studies indicated that need-supportive teaching has a positive impact on students' intrinsic motivation and willingness to learn (Kiemer et al., 2018; Ryan \& Deci, 2017), students' learning engagement (King, 2015; Murray, 2009), and students' well-being (Wang et al., 2021).

\subsection{Language Learning and SDT}

Considerable research shows the usefulness of SDT in education generally. For instance, motivational orientations and engagement are linked to linguistic and communicative capital, as indexed by course grades and standardized test scores (e.g., Butler \& Le, 2018; Pae, 2008). They are also associated with indices of positive psychological capital, including low anxiety and greater linguistic confidence (e.g., Lou \& Noels, 2018). In sum, students who feel satisfied with their psychological needs are more self-determined and engaged in language learning and are likely to achieve academically, linguistically, and psychologically. In a study by Noels, Clément, and Pelletier (1999), English-speaking university students learning French in an immersion program experienced enhanced intrinsic motivation, competence, and lower anxiety in an autonomy-supportive environment, while teachers perceived as controlling and not providing constructive feedback diminished intrinsic motivation. Students with heightened levels of intrinsic motivation for learning French tended to be more successful in and involved with the language immersion course. Another study by Kaur, Hashim, and Noman (2015) provides further support for these findings by designing a detailed unit plan for sixth-grade English language teachers in Thailand to use in their classes. These teachers were trained to incorporate autonomy-supportive teaching behaviors into their own teaching. The results of the intervention program showed that teachers could be trained to teach in an autonomy-supportive manner and thereby promote students' interest, effort, relatedness and integrated regulation. As described, research has demonstrated the relationship between autonomy, competence, and relatedness - the three basic psychological needs of SDT - and intrinsic motivation. In autonomy-supportive learning environments that enhance students' feelings of competence and relatedness, students are much more likely to exhibit intrinsically motivated behaviors such as play, exploration, and curiosity. In addition to skill development, basic need fulfillment has been shown to lead to improved performance, achievement, engagement, and creativity. By incorporating the tenets of SDT into planning and teaching, language teachers can maximize students' interest, engagement, and language achievement.

\section{Research Method}

\subsection{Participants}

In this study, participants were 280 college students from a normal university in the southern area of China (male, $\mathrm{n}=$ 107; female, $\mathrm{n}=167 ; \mathrm{n}=6$ without indication of gender). English is a required subject in this university. The participants were undergraduate freshmen majoring in non-English disciplines, such as business administration, computer science, Japanese, politics and law, electrical engineering and international education of Chinese language, which ensured the consistency of the participants' grades and the diversity of majors. The classes investigated in this study were intensive reading and writing courses in which the students got involved in indifferent kinds of listening, speaking, reading and writing activities.

\subsection{Instrument}

The author referred to Deci and Ryan's (1985) self-determination theory and other studies (e.g., Broeck et al., 2010; Dornyei, 1994; Noels et al., 2000; Noels, 2013; Jones et al., 2009), and designed the questionnaire. Each questionnaire consists of two parts. The first part is multiple-choice questions which mainly examine the students' recognition of PAD Class teaching from three basic psychological needs, namely, the need for autonomy (questions 1-6), the need for competence (questions 7-12) and the need for relatedness (13-20 questions). Likert-type five-point scale was used to measure the questionnaire items, from 1 to 5 representing very disagree, disagree, uncertain, agree and very agree. In order to ensure that the instrument had appropriate psychometric properties, the items were mainly adopted from established questionnaires, with sufficient validity and reliability coefficients. The instrument was submitted to a brief piloting phase, as a result of which the scales were fine-tuned. The measured reliability Cronbach $\alpha$ of the three variables of autonomy, competence and relatedness needs in the questionnaire reached $0.86,0.79$ and 0.82 , which 
ensured the reliability of the survey results. The second part of the questionnaire is an open question and answer, mainly to understand the students' opinions and suggestions on PAD Class from a deeper level.

\section{Results and Discussion}

In the first part of the questionnaire, students had to make their choice from 1 to 5 for each of the 20 questions to give their comments of PAD Class. In this study, the average and standard deviation of the scores for each item in the questionnaire were counted (see Table 1 for the results), trying to evaluate PAD Class from the three levels of autonomy needs, competence needs and relatedness needs. The means of 19 questions are all above 4 points except item 12, which shows that students agree and are satisfied with PAD Class in meeting the basic psychological needs of students.

Table 1. Description and statistical results of each item in the questionnaire

\begin{tabular}{|c|l|c|c|}
\hline No. & \multicolumn{1}{|c|}{ items } & mean & $\begin{array}{c}\text { standard } \\
\text { deviation }\end{array}$ \\
\hline 1 & I can express my personal views and opinions freely in class. & 4.6 & 0.7 \\
\hline 2 & In the classroom, the teacher does not control the classroom too much, we have many choices. & 4.4 & 0.6 \\
\hline 3 & The tasks I need to complete are consistent with what I really want to do. & 4.1 & 0.7 \\
\hline 4 & I am free to complete the task in the best way I think. & 4.8 & 0.8 \\
\hline 5 & In class, I feel that I don't have to be forced to do things I don't want to do. & 4.4 & 0.8 \\
\hline 6 & The teacher's affirmation and encouragement in the class inspired my enthusiasm for learning. & 4.2 & 0.7 \\
\hline 7 & I am very interested in the student questioning session in the class and find it very challenging. & 4.1 & 0.7 \\
\hline 8 & $\begin{array}{l}\text { I am very interested in the debate session in class. It has exercised my ability to think about } \\
\text { problems from different angles. }\end{array}$ & 4.0 & 0.6 \\
\hline 9 & Through group cooperative learning, I have greater confidence in my English learning. & 4.4 & \\
\hline 10 & I feel that I am competent for the learning task. & 4.5 & 0.8 \\
\hline 11 & I am very good at what I want to accomplish. & 4.2 & 0.7 \\
\hline 12 & I feel that I have the ability to complete the most difficult part of the course task. & 3.5 & 0.6 \\
\hline 13. & I feel that I and other students are a closely integrated learning community. & 0.7 \\
\hline 14 & In class, the teacher cares about the students' ideas and respects everyone's different opinions. & 4.5 & 4.7 \\
\hline 15 & $\begin{array}{l}\text { The classroom atmosphere is democratic and harmonious, and the teacher-student relationship } \\
\text { is friendly and harmonious. }\end{array}$ & 4.4 & 0.6 \\
\hline 16 & In my studies, I feel that I can really blend in with other classmates. & 0.8 \\
\hline 17 & I don't feel lonely when I am with my classmates. & 4.2 & \\
\hline 18 & In group learning activities, I am very concerned about the ideas of other group members. & 4.8 & 0.7 \\
\hline 19 & I look forward to sharing my thoughts in class. & 4.1 & 0.6 \\
\hline 20 & I have also established close friendships with some of my study companions. & 4.0 & 0.5 \\
\hline
\end{tabular}

\subsection{PAD Class Promotes the Improvement of Students' English Autonomous Learning Ability}

Autonomous learning is: ' $\ldots$ the ability to think and act critically and independently, to self-manage study and learning, and realistically to appraise one's strengths and weaknesses as a learner' (Crome et al., 2009:112). In PAD Class, the teacher fully believes in and respects the students' personal cognitive level and experience, and gives the students sufficient time and freedom. For instance, during the assimilation phase of PAD Class, students are required to think and explore quietly on their own with clear goals, i.e. complete the tasks assigned by the teacher after the presentation. It is an undisturbed process of thinking and learning individually and independently to fully understand and comprehend the content presented by the teacher. Zhang (2014) pointed out that "students should bring homework to participate in the discussion, and under the pressure of peers, they will study more seriously and actively after class". The results of the questionnaire (see Table 1) show that the average value of the first six items is between "agree" (4 points) and "very agree" (5 points). Students generally believe that they can express their personal views and opinions freely in PAD Class, and are not forced to do things they don't want to do. They feel that the tasks assigned by the teacher are consistent with what they really want to do. In the open questions part of the questionnaire, some students mentioned that PAD Class allowed them to "fully release and show themselves" and feel that they "are enjoying the moment". Some students mentioned that PAD Class made them more "confident and self-disciplined", realizing the transition from "want me to learn " to "I want to learn". The survey conducted by Cui \& Yang (2021) showed PAD Class is medium positive in cultivating students' autonomous learning ability from the dimensions: self-confidence establishment, learning motivation stimulation, learning habit development, and communication or interaction to strengthening. 


\subsection{PAD Class Is Beneficial to the Development of Students' English Thinking Ability}

One of the main goals of university teaching is the cultivation of thinking ability and exploration spirit. The traditional teaching is led by teachers to complete the presentation of established content. The use of various methods is to guide students to cooperate, absorb the content taught by teachers, and think according to the teacher's thinking (Zhong, 2007). PAD Class combines teachers' teaching with students' learning and thinking, encourages students to think independently after class, accept the teacher's teaching critically, form their own opinions, and evaluate each other dialectically in group discussions or intergroup discussions. These thinking training activities are important content of university education and an important way for students to develop their thinking ability. Questions 7 to 12 in the questionnaire of this research examine the satisfaction of students' competence needs in PAD Class. The statistical results show that except for item 12, the average results of all other items are above 4 points. Students generally believe that they are competent for learning tasks and believe that group cooperative learning has strengthened their confidence in learning. Students generally welcome the "student questioning", "debating", "group sharing" and other links in PAD Class. They believe that these activities have exercised their ability to analyze problems from different angles and are challenging. In the open questions section, some students mentioned "no pressure with peers, more active thinking", "more and more like to ask why, more and more critical", "it turns out I can do so well". There are also students who think that the teacher's lectures are not detailed enough and feel that they are not as "reliable" as traditional classrooms. Indeed, for students who are accustomed to traditional teaching, because the teachers in PAD Class have relatively little teaching time and content, they feel that they have not grasped enough knowledge, and some will feel anxious. Therefore, it is a very challenging task for teachers to systematically present the essence of the course to students within the limited teaching time, so that students have a sense of accomplishment.

\subsection{PAD Class Is Conducive to Creating a Harmonious Teacher-Student and Student-Student Relationship}

Traditional classroom teaching is centered on teachers, mainly on teaching and indoctrination, and students are in a state of passively accepting knowledge. The simplification of teaching forms has formed the authority of teachers to students and the dependence of students on teachers. In this unequal relationship, students learn either to obey or resist. The PAD Class puts interactive communication in the classroom, and students bring questions and cooperate with each other to answer together. In this process, the teacher plays the role of a listener, observer and appreciator on the one hand, and at the same time is a partner, supporter and guide of students' learning. In the group discussion, students inspire each other and deepen their understanding. At the same time, they can also enhance mutual understanding and build a deep friendship in study and life. In the open question part of the questionnaire, some students mentioned that there was "no tension" in the English class, and the teacher would not "look down on us". The most enjoyable thing for some students is "showing and sharing with classmates". As Zhang (2016) pointed out that in PAD Class, the discussion stage aims to cultivate students' cooperative learning ability, which reflects the Social Interaction Model and emphasizes information exchange and interpersonal interaction. In the discussion, students form small groups of 4-6 students each, and discuss what they have learned. They clarify and revise their individual learning outcomes with peers in the group discussion, which is conducive to both students' academic and social development. The PAD Class reconstructs the power and responsibility in the classroom, creating a more harmonious and democratic learning community of teachers and students.

\section{Conclusion}

This paper has reviewed and analyzed the college English PAD Class from the perspective of self-determination theory. Through the analysis of the collected data, students are satisfied with PAD Class in meeting their basic psychological needs such as autonomy, competence, and relatedness. PAD Class allows students to have more time to internalize the knowledge taught by teachers, thereby enhancing the initiative of students' learning. In PAD Class, the teachers have only half of the original time to teach the same content, so they only give concise, guiding and frame presentation, leaving students to think and explore quietly on their own with clear goals, i.e. complete the tasks assigned by the teacher after the presentation, thus avoiding the passive "cracking duck" teaching. Equality between teachers and students in PAD Class endows the deserved rights to the students and brings democratic, dialogic, open and free atmosphere to the class, and therefore makes the class be more harmonious, full of fun and full of vitality. PAD Class complies with humanity, releases people's potential and advocates personality (Zhang, 2017). Its advanced teaching concept and rigorous teaching design will be of great significance to teaching reform.

\section{Acknowledgements}

This paper and the study are funded by: Fund Project 1: Research project of Guangdong Education Department "A Study of College English Classroom Ecology Based on the Theory of Ecology of Education (Project No.: 2015GXJK084); Fund Project 2: Research and Practice on the Classroom Teaching Reform of College English Extended Course Group Based on PAD Class Mode. 


\section{References}

Butler, Y. G., \& Le, V. N. (2018). A longitudinal investigation of parental social-economic status (SES) and young students' learning of English as a foreign language. System, 73, 4-15. https://doi.org/10.1016/j.system.2017.07.005

Crome, K., Farrar, R., \& O'Connor, P. (2009) What is autonomous learning? Discourse: Learning and Teaching in Philosophical and Religious Studies 9(1), 111-126. https://doi.org/10.5840/discourse20099112

Cui, Z. H., \& Yang. Y. P. (2021). Research on Effects of Online PAD Class on Autonomous Learning for College English Learners Based on Pearson Test," in 2021 2nd International Conference on Big Data and Informatization Education (ICBDIE), Hangzhou, China, pp. 625-628.

Deci, E. L., \& Ryan, R. M. (1985). Intrinsic Motivation and Self-Determination in Human Behavior. New York: Plenum Press. https://doi.org/10.1007/978-1-4899-2271-7

Dörnyei, Z. (1994). Motivation and Motivating in the Foreign Language Classroom. The Modern Language Journal, 78(3), 273-284. https://doi.org/10.2307/330107

Jones, B. D., Llacer-Arrastia, S., \& Newbill, P. B. (2009). Motivating foreign language students using self-determination theory. Innovation in Language Learning and Teaching, 3(2), 171-189. https://doi.org/10.1080/17501220802358210

Kaur, A., Hashim, R. A., \& Noman, M. (2015). Teacher autonomy support intervention as a classroom practice in a Thai school: A self-determination theory perspective. Multicultural Education, 9(1), 10-27. https://doi.org/10.1108/JME-07-2014-0033

Kiemer, K., Groschner, A., Kunter, M., \& Seidel, T. (2018). Instructional and motivational classroom discourse and their relationship with teacher autonomy and competence support-findings from teacher professional development. European Journal of Psychology of Education, 33(2), 377-402. https://doi.org/10.1007/s10212-016-0324-7

King, R. B. (2015). Sense of relatedness boosts engagement, achievement, and well-being: a latent growth model study. Contemporary Educational Psychology, 42, 26-38. https://doi.org/10.1016/j.cedpsych.2015.04.002

Lou, N. M., \& Noels, K. A. (2018). Western and heritage cultural internalizations predict EFL students' language motivation and confidence. International Journal of Bilingual Education and Bilingualism. https://doi.org/10.1080/13670050.2018.1508277

Murray, C. (2009). Parent and teacher relationships as predictors of school engagement and functioning among low-income urban youth. The Journal of Early Adolescence, 29(3), 376-404. https://doi.org/10.1177/0272431608322940

Noels, K. A., Clément, R., \& Pelletier, L. G. (1999). Perceptions of teachers' communicative style and students' intrinsic and extrinsic motivation. Modern Language Journal, 83(1), 23-34. https://doi.org/10.1111/0026-7902.00003

Noels, K. A., Pelletier, L. G., Clement, R., \& Vallerand, R. J. (2000). Why are you learning a second language? Motivational orientations and self-determination theory. Language Learning, 50(S1), 57-85. https://doi.org/10.1111/0023-8333.00111

Noels, K. A. (2013). Learning Japanese; learning English: Promoting motivation through autonomy, competence and relatedness. In Mathew, T., Apple, D., Silva, D., Fellner, T. (eds.). Language Learning Motivation in Japan. Toronto: Multilingual Matters, 309-325. https://doi.org/10.21832/9781783090518-004

Pae, T. I. (2008). Second Language Orientation and Self-Determination Theory: A Structural Analysis of the Factors Affecting Second Language Achievement. Journal of Language and Social Psychology, 27(1), 5-27. https://doi.org/10.1177/0261927X07309509

Ryan, R. M., \& Deci, E. L. (2017). Self-Determination Theory: Basic Psychological Needs in Motivation, Development, and Wellness. Guilford Press. https://doi.org/10.1521/978.14625/28806

Broeck, A. V. D., Vansteenkiste, M., Witte, H. D., Soenens, B., \& Lens, W. (2010). Capturing autonomy, competence, and relatedness at work: Construction and initial validation of the Work-Related Basic Need Satisfaction Scale. Journal of Occupational and Organizational Psychology, 83, 981-1002. https://doi.org/10.1348/096317909X481382

Wang, Y., Ronnel, B. K., Faming, W., \& Shing, O. L. (2021). Need-supportive teaching is positively associated with students' well-being: A cross-cultural study. Learning and Individual Differences, 92. https://doi.org/10.1016/j.lindif.2021.102051

Zhang, X. X. (2014). PAD Class: A New Exploration of College Classroom Teaching Reform. Fudan University Education Forum, 5, 5-10.

Zhang, X. X. (2016). The PAD Class: New Wisdom of Chinese Education. Beijing: Science Publishing. 
Zhang, X. X. (2017). The PAD Class, A New Paradigm for University Classroom Teaching. In ETOP Proceedings, X. Liu and X. Zhang, eds., (Optical Society of America, 2017), paper 104521X. https://doi.org/10.1117/12.2270967

Zhong, Z. X. (2007). Criticism of Traditional Teaching Design Paradigm (Chinese). Audio-visual Education Research, 2 , 5-7. Classification Code: G420.

\section{Copyrights}

Copyright for this article is retained by the author(s), with first publication rights granted to the journal.

This is an open-access article distributed under the terms and conditions of the Creative Commons Attribution license which permits unrestricted use, distribution, and reproduction in any medium, provided the original work is properly cited. 